\title{
THE EFFECTS OF PHALERIA MACROCARPA EXTRACT ON MITOTIC INDEX AND TUMOR MASS PROGRESSION OF EPIDERMOID CARCINOMA IN SWISS MICE: IN VIVO EXPERIMENTAL STUDY IN SWISS MICE TREATED WITH NEOADJUVANT PACLITAXEL AND CISPLATIN
}

\author{
VITO MAHENDRA EKASAPUTRA ${ }^{1}$, MUHAMAD THOHAR ARIFIN ${ }^{2 *}$, DJOKO HANDOJO ${ }^{3}$ \\ ${ }^{1}$ Department of Surgery, Faculty of Medicine, Sultan Agung Islamic University Hospital, Semarang, Indonesia. ${ }^{2}$ Department of \\ Neurosurgery, Faculty of Medicine, Diponegoro University, Semarang, Indonesia. ${ }^{3}$ Department of Surgery, Division of Surgical Oncology, \\ Faculty of Medicine Diponegoro University, Semarang, Indonesia. Email: thohar@gmail.com
}

Received: 17 July 2019, Revised and Accepted: 21 November 2019

ABSTRACT

Objectives: Polyphenols in Phaleria macrocarpa (mahkota dewa) can inhibit mitogen-activated protein kinase activity in receptor tyrosine kinases pathway. This can be recognized from the decrease of mitotic index as a response to malignant cells and the reduction of tumor development. This study aimed to determine whether P. macrocarpa may decrease the mitotic index and tumor diameter in epidermoid carcinoma.

Methods: The experiment was conducted on 18 epidermoid carcinoma induced Swiss mice divided into four groups: Control, Phaleria administered $\left(0.0715 \mathrm{mg}[0.36 \mathrm{ml}] /\right.$ day), chemotherapy administered (paclitaxel $175 \mathrm{mg} / \mathrm{m}^{2}$ and cisplatin $\left.50 \mathrm{mg} / \mathrm{m}^{2}\right)$, and combination group. Tumor size diameter was measured before and after treatment in 9 weeks. Mitotic index was measured at the end of the treatment.

Results: There were significant differences in the mitotic index and changes in tumor diameter among groups compared with the control group. The most significant growth inhibition and decrease in mitotic index were in group four. There was a significant positive correlation between tumor mitotic index and changes in tumor diameter $(\mathrm{r}=0.813)$.

Conclusion: $P$. macrocarpa is able to decrease tumor cells' mitotic index and inhibit epidermoid carcinoma's tumor mass progression in Swiss mice.

Keywords: Phaleria macrocarpa, Mitotic index, Tumor diameter, Epidermoid carcinoma.

(c) 2020 The Authors. Published by Innovare Academic Sciences Pvt Ltd. This is an open access article under the CC BY license (http://creativecommons. org/licenses/by/4. 0/) DOI: http://dx.doi.org/10.22159/ajpcr.2020.v13i1.34971

\section{INTRODUCTION}

Skin malignancy is the most prevalent in Indonesia after cervix cancer and breast cancer [1-3]. Non-melanoma skin cancer represents the most common cancer diagnosed in the world, with 2-3 million incidents reported globally. Epidermoid cancer is a high recurring non-melanoma skin cancer type that is most diagnosed after basal cell carcinoma. According to the National Cancer Institute, the recurrence rate after primary therapy reaches $3-23 \%$ depending on the anatomical location. About 58\% of cases recur locally in 1 year, $83 \%$ in 3 years, and $95 \%$ in 5 years. The frequency of primary tumor metastasis in skin exposed to sunray is $5 \%$ on external auricular and $9 \%$ on lips. A higher frequency at about $38 \%$ is observed in squamous cell carcinoma on chronic scar skin. The frequency of metastasis diagnosed in 1 year is $69 \%$, in 3 years is $91 \%$, and in 5 years is $96 \%$. Tumor with $2 \mathrm{~cm}$ diameters or more and $4 \mathrm{~mm}$ depth or more, and poorly differentiated has a worse prognosis and higher local recurrence rate [4]. Report from the American Cancer Society stated that epidermoid carcinoma has high recurrence rate between $2 \%$ and $9 \%$ on a wide excision that is $2 \mathrm{~cm}$ from the tumor border, between $7 \%$ and $50 \%$ in post-radiotherapy cases, and $20 \%$ in post-curettage and electrodissection cases [2].

With such a high recurrence rate, treating epidermoid carcinoma is not easy. Operative therapy, radiotherapy, and biology targeting therapy are often ineffective and patients are often forced to undergo cytostatic therapy, which is often unaffordable and has a toxic effect that harms vital organs $[5,6]$. Therefore, an alternative therapy for epidermoid cancer using herbal plant might be a viable solution. Recently, herbal therapy has been an affordable alternative to treat many diseases and the outcome thus far has been satisfying [7].
One widely known herb plant in Indonesia, Phaleria macrocarpa (Scheff and Boer) (mahkota dewa) has been used as an alternative medicine in cancer therapy, widely sold as anticancer agents with 5-g doses/day. It contains alkaloid, flavonoid, polyphenol, resin, tannin, and many more bioactive agents that serve as selective anti-inflammatory, antiproliferative, and antiangiogenic on breast and cervical cancer cells $[8,9]$.

Polyphenol in P. macrocarpa can block growth factor receptor and inhibit mitogen-activated protein kinase (MAPK) on receptor tyrosine kinases (RTKs) signaling pathway [10-12]. The study from Deguchi et al. found that polyphenol in herbal medicine has an inhibition effect on MAPK [13-14]. Polyphenol also blocks any RTKs pathways that facilitate cell mitosis such as epidermal growth factor receptor (EGFR), platelet-derived growth factor receptor (PDGF), and fibroblast growth factor receptor (FGR) [11,12].

\section{METHODS}

We performed study trials twice according to the chemotherapy cycle in 3 cycles at 3 weeks interval. Chemotherapy and P. macrocarpa administration was done in Lembaga Penelitian dan Pengujian Terpadu laboratory, Gajah Mada University, Yogyakarta, from February 2014 to September 2014. This study was approved by the Ethical Committee of the Faculty of Medicine, Diponegoro University.

The experimental design was pretest-posttest with a control group. Twenty-four Swiss mice were used in this trial. To induce epidermoid carcinoma, the interscapular $1.5 \mathrm{~cm} \times 1.5 \mathrm{~cm}$ hairy area was cleaned up. The carcinogenic agent of $100 \mathrm{nmol}(0.025 \mathrm{mg})$ of 9, 12-dimethyl1,2-benzanthracene in $0.1 \mathrm{ml}$ acetones was topically applied twice a 
week in 2 consecutive weeks. This was followed by the application of $1.7 \mathrm{nmol}(0.001 \mathrm{mg})$ topical 12-o-tetradecanoyl phorbol-13-acetate dissolved in $0.1 \mathrm{ml}$ acetones twice a week in 22 consecutive weeks. The mice were then divided into four groups, consisting of three treatment groups (T1-T3) and one control group (V). Treatment groups in their respective order were treated with (a) $0.0715 \mathrm{mg}(0.36 \mathrm{ml} /$ days $)$ of P. macrocarpa extract, (b) $175 \mathrm{mg} / \mathrm{m}^{2}$ paclitaxel and $50 \mathrm{mg} / \mathrm{m}^{2}$ cisplatin, and (c) $175 \mathrm{mg} / \mathrm{m}^{2}$ paclitaxel and $50 \mathrm{mg} / \mathrm{m}^{2}$ cisplatin followed by $0.0715 \mathrm{mg}(0.36 \mathrm{ml} /$ days $)$ of $P$. macrocarpa extract in 9 weeks.

Hematoxylin-eosin staining was performed to analyze the mitotic index using the method by Aihara et al. The mitotic cell in 100 tumor cells was counted using $\times 400$, in five different fields of view, then the percentage was calculated. Tumor size was measured using tumor caliper (CaliProR) with $1 \times 10^{-2}$ accuracy. The centimeter measurement looked at the longest diameter in every tumor site, taken before and after treatment.

All data were observed as descriptive with mean \pm SD. The tumor size measurement was performed by using Kruskal-Wallis test. This was followed by Mann-Whitney test to measure the mitotic index in all groups. Spearman test was then used to analyze the correlation between mitotic index and tumor size. All data were analyzed in SPSS version 15 (IBM, USA). The results were considered significant if $\mathrm{p} \leq 0.05$ and confidence interval was $95 \%$.

\section{RESULTS}

After successful tumor induction was confirmed by a pathologist after 9 months, the treatment trials were initiated. After 9 weeks of treatment, the T3 group showed a significant decrease in tumor size compared to pre-treatment (Tables 1 and 2). There was also a significant decrease in mitotic index in all groups (Table 3 and Fig. 1). Normal and homogenous data were obtained from each group in terms of tumor size ( $p>0.05)$.

Mann-Whitney test showed that there was a significant difference in tumor size $(\mathrm{p}=0.049)$ between $\mathrm{V}$ and $\mathrm{T} 1$ group, $\mathrm{V}$ and $\mathrm{T} 2$ group, $\mathrm{V}$ and $\mathrm{T} 3$ group, and $\mathrm{T} 1$ and $\mathrm{T} 3$ group (Fig. 2). There was a significant difference in mitotic index between Groups $\mathrm{V}$ and $\mathrm{T} 1, \mathrm{~V}$ and $\mathrm{T} 2, \mathrm{~V}$ and $\mathrm{T} 3$, T1 and T3, and $\mathrm{T} 2$ and $\mathrm{T} 3$ ( $\mathrm{p}=0.043$ ) (Fig. 3).

There was a significant correlation between tumor size and mitotic index ( $\mathrm{p}=0.001$ ) with $\mathrm{r}=0.813$ (Fig. 4). Thus, there was a strong and positive correlation between the decreasing mitotic index and the decreasing tumor size.

Table 1: Mean tumor diameter in each group (in cm)

\begin{tabular}{lllll}
\hline Group & Control & T1 & T2 & T3 \\
\hline Before treatment & 1.3 & 0.56 & 1.1 & 0.96 \\
After treatment & 2.4 & 1 & 1.5 & 0.7 \\
\hline
\end{tabular}

Table 2: Average tumor size and mitotic index difference between pre-treatment and treatment group

\begin{tabular}{llll}
\hline Variable & Mean \pm SD & Median (min.-max.) & $\mathbf{p}$ \\
\hline Tumor size difference & $0.42 \pm 0.537$ & $0.4(-0.5-1.4)$ & 0.999 \\
Mitotic index & $1.52 \pm 1.046$ & $1.1(0.6-3.4)$ & 0.002 \\
\hline
\end{tabular}

SD: Standard deviation

Table 3: Mitotic index in each group

\begin{tabular}{llll}
\hline Group & Mean \pm SD & Median (min.-max.) & p \\
\hline C & $3.2 \pm 0.346$ & $3.4(2.8-3.4)$ & 0.000 \\
T1 & $1.13 \pm 0.115$ & $1.2(1-1.2)$ & 0.000 \\
T2 & $1.07 \pm 0.115$ & $1.0(1-1.2)$ & 0.000 \\
T3 & $0.67 \pm 0.115$ & $0.6(0.6-0.8)$ & 0.000 \\
\hline
\end{tabular}

Levene test $=0.026$, C: Control, SD: Standard deviation

\section{DISCUSSION}

In this study, we found that there was a significant difference between control group and treatment groups $(\mathrm{p}=0.049)$. Even though we did not find any regression in tumor size, a significant inhibition of tumor development was shown in this study. A previous study by Budijitno stated that $P$. macrocarpa to treat adenocarcinoma mammae in mice also showed a similar tumor size inhibition effect [15]. Another report demonstrates that $P$. macrocarpa has a growth-blocking effect in a factor receptor and inhibits MAPK in RTKs signaling pathway [11,12]. Evidence shows how P. macrocarpa blocks several RTKs, such as EGFR, PDGF, and FGR. Thus, it can inhibit RTKs signaling pathway in regulating cell mitotic, differentiation, survival, and cell metabolism by p21 $[13,14]$.

The decrease of mitotic index in treatment groups may have owed to polyphenol contained in P. macrocarpa extract that blocks growth factor receptor in RTKs signaling pathway and inhibits MAPK, causing inhibition in a primary signal transfer of MAPK from the membrane to the nucleus. This condition will push a cell to start the G0 phase and stop mitotic [11,12]. A higher decrease of mitotic index was shown in T3 after the tumor was treated with a combination of chemotherapy drugs paclitaxel - cisplatin and P. macrocarpa at $0.0715 \mathrm{mg} /$ days ( $0.36 \mathrm{ml} /$ days). The decrease was more significant compared to group treated only with $P$. macrocarpa extract at $0.0715 \mathrm{mg} /$ days

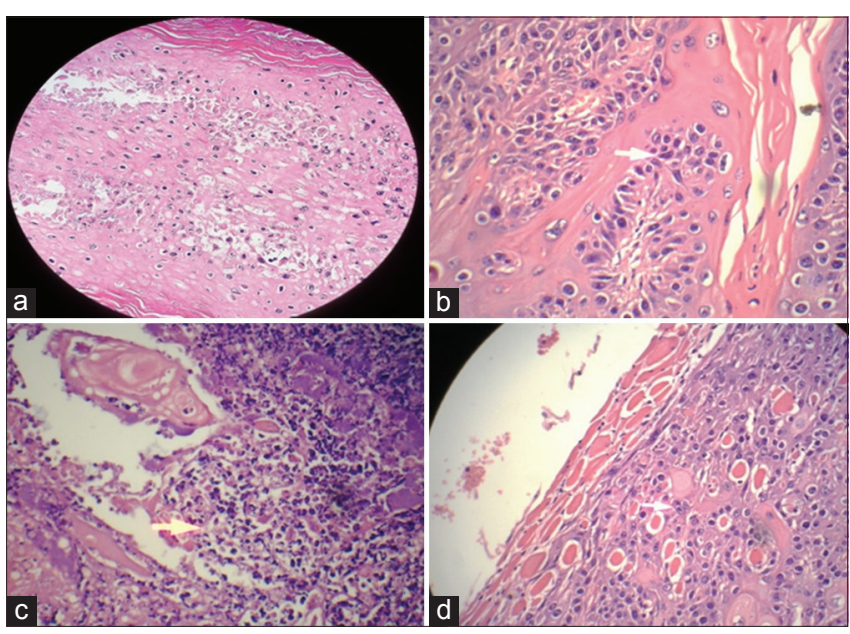

Fig. 1: Hematoxylin and eosin staining of epidermoid carcinoma tissue. (a) Mitotic appearance on control group. (b-d) Mitotic cells in $\mathrm{T} 1, \mathrm{~T} 2$, and $\mathrm{T} 3$ group, respectively

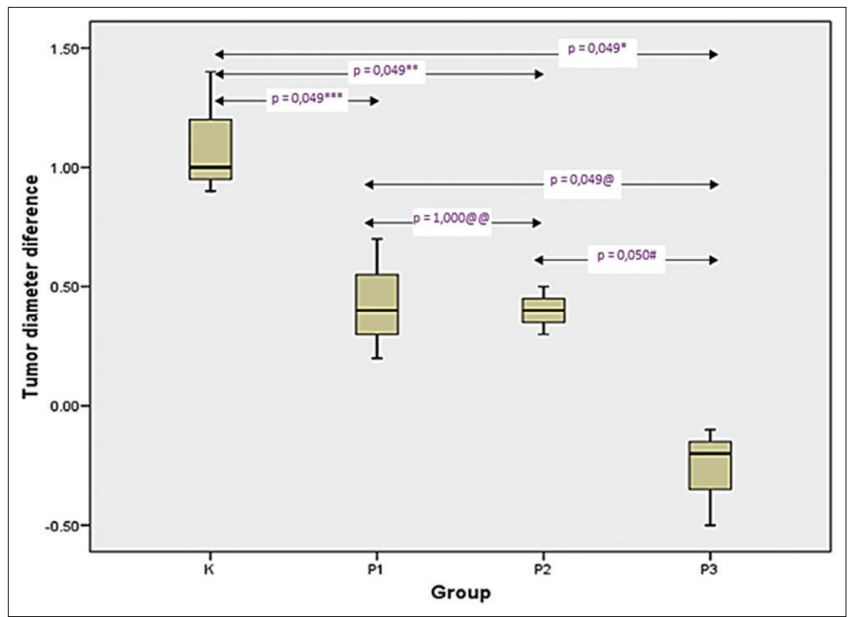

Fig. 2: Mann-Whitney test on tumor size indicating that there is a significant difference between groups. (K: Control; P1: T1 group; P2: T2 group; P3: T3 group) 


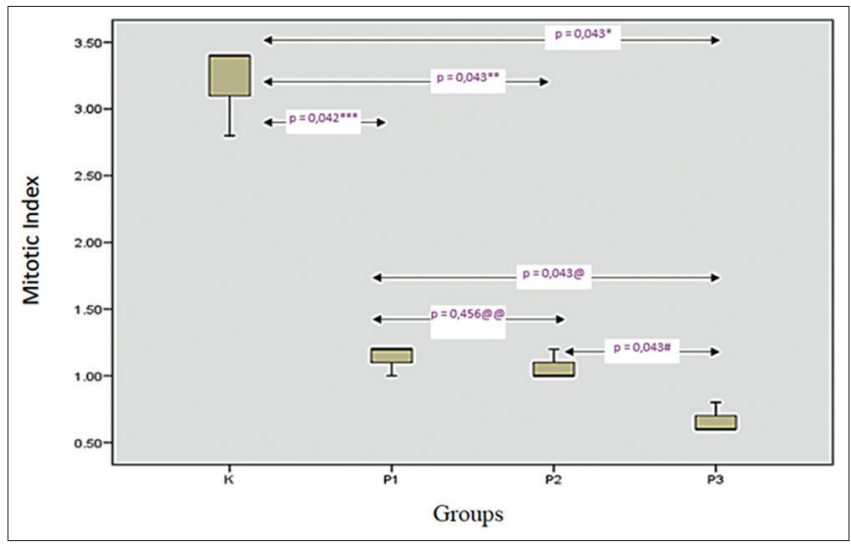

Fig. 3: Mann-Whitney test on mitotic index indicating that there was a significant difference between groups. (K: Control; P1: T1 group; P2: T2 group; P3: T3 group)

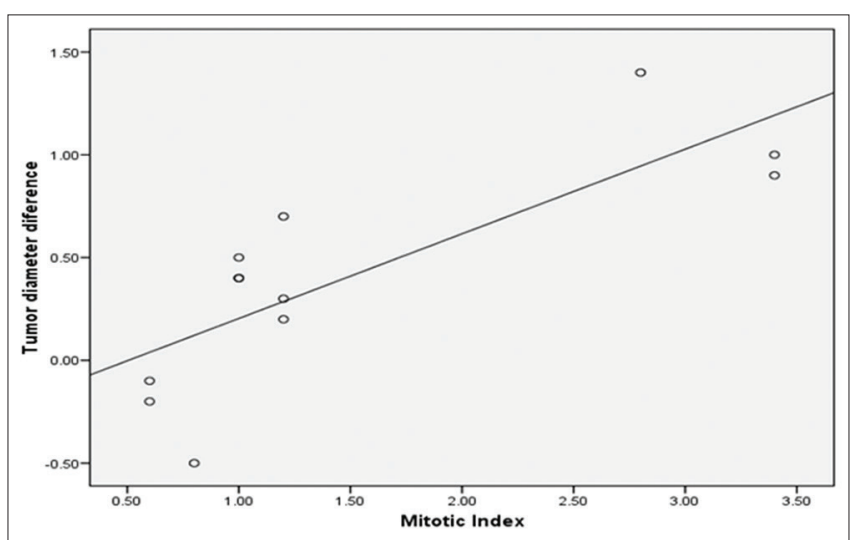

Fig. 4: Correlation chart using Spearman test between tumor size and mitotic index

( $0.36 \mathrm{ml} /$ days) (T1) or only chemotherapy only paclitaxel - cisplatin (T2). This might indicate that there is a synergetic effect between polyphenol in P. macrocarpa and cytostatic drugs that inhibit cell proliferation by inducing a mitotic block in metaphase/anaphase. Together it could form an incomplete metaphase plate in the chromosome, so the microtubule spindle regulation becomes abnormal. Cisplatin works by inhibiting the crosslink from DNA and actively disrupting cell cycle [6].

As there is a strong and positive correlation between the mitotic index and tumor size decrease, every decrease in the mitotic index will be followed by a decrease in tumor size. In this study, there was no regression in tumor size after the treatment compared to the pre-treatment state. However, there was a significant decrease in tumor size in the group that used a combination of cytostatic drugs and P. macrocarpa, which not only inhibited mitotic activity but also tumor size in terms of its macroscopic appearance. Inhibition of tumor growth might be due to the decrease in cell mitosis. Another possibility may come from apoptotic and cell differentiation. To ensure which one contributes significantly to the decrease, further investigation is needed to examine the correlation between apoptotic index and tumor size.

P. macrocarpa has been known to have anti-inflammatory, antiproliferative, and antiangiogenic effects on breast, cervical cancer cells, and inhibit colonic inflammation $[8,9,16]$.

\section{CONCLUSION}

From this study, we conclude that Phaleria macrocarpa extract has a potent immunomodulator and a cytostatic effect. Clinically, the combination between Phaleria macrocarpa and cytostatic drugs such as Paclitaxel and Cisplatin may reduce the mitotic index of epidermoid carcinoma and may inhibit tumor size. Thus, Phaleria macrocarpa could be used as an alternative adjuvant therapy to cytostatic drugs in treating epidermoid carcinoma.

\section{AUTHORS' CONTRIBUTIONS}

V.M.S was responsible for study design, data collection, and data analysis. M.T.A and D.H were responsible for study design, data analysis, and manuscript writing.

\section{CONFLICTS OF INTEREST}

All authors declare that they have no financial conflicts of interest.

\section{REFERENCES}

1. Nouri K. Skin Cancer: Squamous Cell Carcinoma of the Skin. New York: McGraw Hill; 2008. p. 86-110.

2. American Cancer Society. Cancer Facts and Figure; 2003. Available from: http://www.cancer.org/downloads/STT/CAF.secured.pdf.

3. Pasaribu ET, Suryatno S, Riefmanto BH. Bedah Onkologi Diagnosis Dan Terapi. $1^{\text {st }}$ ed. (Original article in Indonesian). Jakarta: Sagung Seto; 2010.

4. Thompson AK, Kelley BF, Prokop LJ, Murrad MH, Baum CL. Risk factors for cutaneous squamous cell carcinoma outcomes: A systematic review and meta-analysis. JAMA Dermatol 2016;152;419-28.

5. Gniadecki R. Non Surgical Treatment of Keratinocyte Skin CancerSystemic Chemotherapy of Non Melanoma Skin Cancer. Berlin: Springer-Berlin; 2010.

6. Baretta G. Cancer Treatment Medical Guide. $11^{\text {th }}$ ed. Milan: Farmitalia Carlo Erba Erbamont; 2001. p. 174-6.

7. Winarto WP. Mahkota Dewa: Budi Daya dan Pemanfaatan Untuk Obat (Original article in Indonesian). Jakarta: Penebar Swadaya; 2004.

8. Tjandrawinata R, Djunarko I, Fenty F, Hendra P. Anti-inflammation effects of bioactive fraction DLBS0533 containing Phaleria macrocarpa and Nigella sativa on animal model. Int J Pharm Pharm Sci 2015;7:408-11.

9. Tjandrawinata R, Rouli H. A role for Phaleria macrocarpa (Scheff Boerl) extracts in the management of women's pathological conditions: A research review. Int J Pharm Pharm Sci 2017;9:7-12.

10. Lisdawati V. Phaleria macrocarpa, Toksisitas, Efek Anti Oksidan dan Efek Anti Kanker Berdasarkan Uji Penapisan Farmakologi (Original article in Indonesian). Jakarta: PT Mahkota Dewa; 2002.

11. Sumastuti R, Sonlimar M. Efek Sitotoksik Ekstrak Buah dan Daun Mahkota Dewa (Phaleria macrocarpa) Scheff Boerl Terhadap Sel Hela (Original article in Indonesian). Yogyakarta: Farmakologi FK UGM; 2003.

12. Faried A, Kurnia D, Faried LS, Usman N, Miyazaki T, Kato H, et al. Anti cancer effects of gallic acid isolated from Indonesian herbal medicine, Phaleria macrocarpa (Scheff) boerl on human cancer cell lines. Int J Oncol 2007;30:605-13.

13. Deguchi H, Fujii T, Nakagawa S, Koga T, Shirouzu K. Analysis of cell growth inhibitory effect of cathecin through MAPK in human breast cancer cell line T47D. Int J Oncol 2002;21:1301-5.

14. Ahmad N, Muhtar H. Green Tea Polyphenols and Cancer: Biologic Mechanism and Practical Implication. Cleveland: University Hospital of Cleveland; 1999. p. 78-83.

15. Budijitno S. Pengaruh Ekstrak Phaleria macrocarpa Terhadap Skor Ekspresi Perforin CTL dan Sel-NK Serta Indek Apoptosis pada Adenokarsinoma Mammae Mencit C3H. Vol. 42. (Original article in Indonesian) Majalah MMI; 2007. p. 13-9.

16. Estuningtyas A, Widiasari S, Kusmardi K. Acute toxicity of chitosan nanoparticles containing mahkota dewa (Phaleria macrocarpa) leaf extract and anti-inflammatory effects in a dextran sodium sulfate-induced mouse model of ulcerative colitis. Int J Appl Pharm 2018;10:6-10. 